\title{
Transformations of Eastern Orthodox Religious Discourse in Digital Society
}

\author{
Yana A. Volkova (iD \\ Department of Foreign Languages in Theory and Practice, Peoples' Friendship University of \\ Russia (RUDN University), 117198 Moscow, Russia; volkova-yaa@rudn.ru
}

Citation: Volkova, Yana A. 2021. Transformations of Eastern Orthodox Religious Discourse in Digital Society. Religions 12: 143. https://doi.org/ $10.3390 /$ rel12020143

Academic Editors

Svetlana Sharonova and Enzo Pace

Received: 24 January 2021

Accepted: 19 February 2021

Published: 22 February 2021

Publisher's Note: MDPI stays neutral with regard to jurisdictional claims in published maps and institutional affiliations.

Copyright: (C) 2021 by the author. Licensee MDPI, Basel, Switzerland. This article is an open access article distributed under the terms and conditions of the Creative Commons Attribution (CC BY) license (https:// creativecommons.org/licenses/by/ $4.0 /)$.

\begin{abstract}
Digital technologies have exerted a profound influence on every aspect of human life including religion. Religious discourse, like no other type of social-communicative interaction, responds to the slightest shifts in the concepts of life, identity, time, and space caused by digitalization. The purpose of this study was to reveal the digitalization-associated transformations that have taken place in the eastern orthodox religious discourse over more than quarter of a century. This discussion focuses on the attitude of the Russian Orthodox Church towards digital technologies as reflected in the interviews of its official spokespeople. On the basis of extensive empirical material, it is shown that two major factors determine new tendencies in eastern orthodox religious discourse: the necessity to adapt to modern digital environment and benefit from organizing the internet space in order to influence large numbers of "digitally educated" non-religious people, and, at the same time, a distrust of these new digital technologies. The study is based on the theory of discourse, with discourse analysis being the main research method along with the descriptive analytical method. The article also analyzed the changes in traditional genres of eastern orthodox religious discourse (the sermon), as well as the rapid development of new religious discourse genres (the commented liturgy and call-in show) and para-religious discourse genres. It is concluded that with the help of digital technologies, religious discourse penetrates into everyday life of people, regardless of their social status and religious affiliation, eliminating the borderline between the church and society in modern Russia.
\end{abstract}

Keywords: eastern orthodoxy; religious discourse; speech genre; digital society

\section{Introduction}

Digital technologies have a profound influence on every aspect of human life, and religion is no exception, since digital means have transformed the concepts of life, identity, time, and space. The attitude of the Russian Orthodox Church towards new digital technologies was clearly indicated in 2003, in an interview) with Archpriest Vsevolod Chaplin, the then Head of the Department for External Church Relations of the Moscow Patriarchate, in which he expressed the hope that the Internet would become a means of demonopolizing a large information space (https: / / www.osp.ru/pcworld/2003/05/16 5719 (accessed on 27 December 2020)). In general, digital technologies have been viewed as a convenient tool to expand religious influence and reach the hearts and souls of potential church-goers, to make the religious picture of the world more expressive and plausible. A special search engine Pravoslavniy Internet (http://www.hristianstvo.ru/ internet/ (accessed on 4 January 2021)) provides access to 99 webportals, 993 electronic libraries, 442 internet shops, 504 web forums, 576 users' home pages, and other resources. Pravoslavniy Internet also comprises its own social network, dating sites, and blogs. Almost all organizations and structures of the Russian Orthodox Church have official websites that are regularly updated (see: http: / / www.patriarchia.ru/db/organizations / (accessed on 4 January 2021)). The most popular Russian social network VK (VKontakte) includes dozens of eastern orthodox groups, the most popular of which are Veruyu. Pravoslaviye (I 
Believe. The Russian Orthodoxy) with 1,864,920 subscribers, Pravoslaviye-okean mudrosti (The Russian Orthodoxy, the ocean of wisdom) with about 230 thousand subscribers and participants, Dobroye Slovo. Pravoslaviye (A Good Word. The Russian Orthodoxy) with more than 350 thousand participants, Pravoslavniye (The Orthodox people) with about 200 thousand participants, Svyatiye Otsi. Pravoslaviye (The Holy Fathers. The Eastern Orthodoxy) with about 130 thousand participants, and many others. A similar picture can be observed on Facebook. Many such groups consider themselves not only religious, but socio-political as well. Organized by either clergymen or secular persons, these groups discuss the Russian national idea, the history and future of Russia, as well as numerous religious issues. This small selection shows that religious aspects of life are no longer a deeply personal matter; in fact, they have gone beyond the scope of traditional religious discourse, attending church, and saying prayers, and it is the Russian Orthodox Church themselves that have initiated the process of the transformation of the religious discourse.

\section{The Russian Orthodox Church and the Internet}

This section is a look at the changing attitude of the Russian Orthodox Church (ROC) towards digital technologies over the last quarter of a century. The attitude of the official Russian Orthodox Church towards the Internet as the most tangible product of the digital age has been rather mixed. In 2004, His Holiness Patriarch Alexy II of Moscow and All Russia congratulated the Russian Internet community on the 10th anniversary of the Russian Internet. In his address, Patriarch Alexy II said,

"The Church of Christ has always had the understanding that knowledge about the Truth should be spread as widely as possible. Currently, the Internet provides exceptional opportunities in this regard, and the Church has no right to neglect them. $\langle\ldots>$ Modern communication and information technologies open up hitherto unprecedented prospects of preaching about Christ, truly 'even to the ends of the earth' (Acts 1. 8). Therefore, the Russian Orthodox Church, in order to carry out its salvific ministry, pays special attention to interaction with the media, to the process of mastering the latest information technologies. Thanks to the Internet, our Church has the opportunity to widely inform network users about the most important news of church life, the activities of the Holy Synod, about external church relations, the development of church-state and churchpublic relations, about the events of diocesan life, about peacemaking, social and charitable ministry." (https://mospat.ru/archive/2004/11/26156/ (accessed on 4 January 2021) ${ }^{1}$

A year later in his interview to the Interfax agency, Patriarch Alexy II confirmed his position by saying that "the Church blessed the use of the Internet." (http:/ / www.interfaxreligion.ru/?act=news\&div=4514 (accessed on 4 January 2021)) Answering those who claimed that modern technologies were a source of immorality, he stated,

"It is quite obvious that the Internet, television are simply technical means that can be used in different ways. It is unacceptable to neglect them just because someone has placed them in the service of sin and vice. $<\ldots>$ The World Wide Web has long been a medium for Christian evangelism and our resources in this direction are far from being exhausted." (http:/ / www.interfax-religion.ru/?act= news\&div=4514 (accessed on 4 January 2021))

Under Alexy II, a number of religious websites and web-portals were created in the Russian Internet space, among which are the website Orthodox Christianity in Russia (1997), the official web-server of the Russian Orthodox Church (1997), the official website of the Moscow Patriarchate (1997), the webpage of the Cathedral of Christ the Savior (2000), educational portal of the Study Committee of the Russian Orthodox Church (2002), the website of the Pilgrimage Center of the Moscow Patriarchate (2003), the website of the

1 Hereinafter, the translations of the citations are performed by the author (Y.V.). 
Moscow Theological Academy (2005), the web-portal Patriachia.ru (2005); the now closed website Pravoslavnoye Povolzhye (Orthodox Christianity in the Volga Region) (2007), and many others.

However, after the Patriarch's death in 2008, the attitude of the ROC officials towards the Internet began to change. The first signs could not go unnoticed in the address of Metropolitan Clement to the Civic Chamber of the Russian federation on 25 March, 2009. The very topic of the discussion was Internet Communication: Cultural Revolution or Cultural Degradation, and the Metropolitan stated that despite all the positive features of the worldwide web, "communication on the Internet has become an indicator of cultural degradation. $\langle\ldots\rangle$ In a society that neglects cultural values due to insufficient education, there is a decline in morality, an increase in the number of asocial phenomena." (http: / / www.patriarchia.ru/db/text/597095.html (accessed on 4 January 2021)). Two years later, Archpriest Vsevolod Chaplin, Head of the Department for External Church Relations of the Moscow Patriarchate, whose positive evaluation of the Internet opportunities for the ROC in 2005 was quoted at the beginning of this article, suggested placing anonymous members of the Internet community in a special "danger zone". He compared the anonymous Internet users with robbers, souteneurs, and other types of criminals (http:/ / www.interfaxreligion.ru/?act=news\&div $=40784$ (accessed on 4 January 2021)). In fact, since the 2010s the attitude of the ROC towards the Internet has undergone dramatic transformation-we could not find any unambiguously positive assessment of the Internet in the official sources of the ROC. For example, speaking at the Bishops' Council of the Russian Orthodox Church in 2013, Patriarch Kirill of Moscow and All Russia said,

"When a person asks a query related to church life in an Internet search engine, he finds a lot of lies, hypocrisy and hatred. These are the visible results of the activities of the Archenemy. $<\ldots>$ The image of a person who lives primarily in the media space is far from the Christian ideal. The beauty of God's world cannot be replaced with the space for communication artificially created by people." (https:/ / mospat.ru/ru/2013/02/02/news80272/ (accessed on 4 January 2021))

In the same year Patriarch spoke against the presence of the Internet in Orthodox Monasteries (https:/ / ria.ru/20130608/942275418.html (accessed on 6 January 2021)). In his 2014 Christmas interview to the TV channel Rossia, Patriarch Kirill called spending days on the Internet "a sign of a spiritual crisis", and the Internet itself- "a kingdom of crooked mirrors", making allusion to a children's fairy-tale where the protagonist finds herself in a kind of through-the-looking-glass reality in which people are brainwashed with the help of crooked mirrors (https: / / www.youtube.com/watch?v=jZFCse7kW4M (accessed on 6 January 2021))).

In subsequent years, Patriarch Kirill repeatedly warned believers against the dangers of social networks and the destructive power of the Internet and digital technologies on the whole. The strongest message was delivered during the 2019 Christmas interview when the Patriarch said,

"Control from one center is the antecedent of the Antichrist in Christian perspective. The Antichrist is the person who will be at the head of the World Wide Web that controls the entire human race. This means that the structure itself is dangerous. There should be no single center. At least for the foreseeable future, if we ourselves do not want to bring the apocalypse closer. Therefore, the gadget is good. In terms of convenience and pleasure. But from the perspective of control over the human personality, this is a dangerous business. And the church should speak about this, realizing that it will incur anger." (https://www.youtube.com/watch?v=eqSNNIrKu1c (accessed on 6 January 2021))

This message was developed and enhanced in his last Christmas interview, in the answer to the question what areas, spheres of digitalization require special comprehension. Patriarch Kirill said the following: 
"I will not talk about digitalization in principle, but would like to talk about individual applications of digital technologies. Digital technologies are able to create tools that provide total control over a person. Nothing like this could have happened in the past. Human thought, technical civilization today have reached such a level when, by introducing digital technologies, it is possible to ensure total control over the human personality. Not just observing a person, but managing human behavior. The book of the Apocalypse says that the coming of the Antichrist will be accompanied by total control over a person. These words are not used there, but from the content it is quite clear that we are talking about the ability to totally control human behavior. It says that the seal of antichrist will be imposed on a person's forehead, and without this seal it will be impossible to buy, sell, or participate in any social relations-the person will be doomed to death." (https: / / www.youtube.com/watch?v=Mfjo0QNYGm0 (accessed on 8 January 2021))

It seems quite natural that the primate's opinion is reflected in the positions of the junior ranks of the ROC officials. For example, Mark Markish, Head of the IvanovoVoznesensk Diocese Department for Relations between the Church, Society, and the Media, said that abuse of the Internet and other modern technologies alienates a person from the church and God,

"Instead of going to church and ascending to God, a person presses a button and looks at what they write on the Internet. They press a button and see what is allowed to do during fasting and what is not, and that's it. Abuse of technology is the scissors that cut a person off from God, from the church." (https: / / lenta.ru/news/2019/06/25/interesting/ (accessed on 8 January 2021))

Thus, the provided material demonstrates the shift in the "church vs. digital technologies" reaction discourse over the last 20 years. At the onset of the World Wide Web epoch, in its rhetoric, words and structures with positive evaluative meaning prevailed: "exceptional opportunities", "blessing", "a medium for Christian evangelism", etc. The Internet was perceived as a perfect technological tool for spreading the Word of God throughout the world; new opportunities appeared fascinating, and the ROC seemed to be relying on the newly introduced digital technologies in fulfilling its evangelistic and educational mission. Although the negative aspect of digital technologies was fully realized, their benefits outweighed the disadvantages, with the general positive and optimistic attitude being predominant. The present-day attitude appears to be diametrically opposed to the original one. Digital technologies in general and the Internet in particular are still viewed as a convenient tool of communication, but nowadays their negative/evil aspect is being emphasized-it is described with such phrases as "the antecedent of the Antichrist", "alienate from God", "bring the apocalypse closer", "a dangerous business", "total control over the human personality", etc. The COVID-19 pandemic seemed to have exacerbated the situation - even though the church is forced to use digital technologies due to anticoronavirus measures, it still resists them; on the one hand, the ROC had to increase the number of online broadcasts of church services, on the other, the church officials announced that no sacraments would ever be performed through the Internet or using other digital technologies (https:/ /rg.ru/2020/04/04/rpc-uvelichivaet-chislo-transliacij-sluzhb-no-tainstva-vinternet-ne-perejdut.html (accessed on 8 January 2021)). Moreover, the ROC called to protect Christians from new technologies, claiming that the lack of regulatory measures in the field of digital technologies in Russia infringes the rights of those Christians who do not want to use new technologies. Orthodox Christians should be protected from "digital totalitarianism", since living under the totalitarian digital control is unacceptable for a Christian (https:/ / news.mail.ru/society / 44281423 / (accessed on 8 January 2021)).

Thus, the foregrounding of the negative aspect of digital technologies inevitably leads to distorting their perception in religious discourse and in the mentality of Orthodox Christians since the Internet (as a most vivid demonstration of digital technologies) is 
incompatible with Christian norms and values. Religious discourse is highly manipulative in its nature. Therefore, it does not seem surprising that according to the non-state research organization Levada-Center, the number of Russians who believe in religious miracles is constantly growing (https:/ / www.levada.ru/2020/10/28/vera-v-sverhestestvennoe/ (accessed on 8 January 2021)), making up 52\% in 2020 against 44\% in 2018. The share of those who believe in religious miracles is at least 1.5 times higher among regular churchgoers than among Orthodox Russians who do not attend church at all. It may mean that for all those people digital technologies remain just handy instruments of communication and pleasure, which do not interfere with or transform their conceptual system.

\section{Theoretical Foundations of Discourse Studies}

Discourse became the focus of linguistic studies in the 20th century when the works by M. Bachtin, R. Barthes, J. Baudrillard, T. van Dijk, M. Foucault, Y. Lotman, and U. Eco formed the basis for the discursive approach to the research of various speech practices. In this section, two basic approaches to discourse are briefly outlined to provide a general background of modern discourse studies.

There exists a considerable difference between the philosophical and linguistic approaches to discourse. The father of the philosophical approach, Michel Foucault, defines discourse as a number of statements subordinate to the mechanism of the existence of statements. He further introduces the concept of discursive formations-special unities that form a discourse and serve as the real context determining the life of language (Foucault 1972). In terms of Foucault's theory, discourse can be treated as "a virtual domain that actually functions as a mechanism that determines what is said" (Burtsev 2012), the virtual being understood in the sense that for any discourse there is no correlation in the form of a continuous and homogeneous text. Returning to the discursive formation, it should be noted that in terms of archaeological theory of discourse analysis, it can be treated as a material structure formed by a set of statements on the usage of which certain limits are imposed, since one should know what can or cannot be said in a particular space of knowledge. These discursive events are embodied in utterances, which are traditionally considered one of the few links between Foucault's conception and the linguistic theory.

"The analysis of lexical contents defines either the elements of meaning at the disposal of speaking subjects in a given period, or the semantic structure that appears on the surface of a discourse that has already been spoken." (Foucault 1972, p. 48)

The above quotation is a possible illustration to the fact that in Foucault's understanding, discourse is fundamentally different from the perspective adopted in the Russian linguistic tradition, which this research is based on. However, the approach by Stepanov can be considered somewhat similar since it involves a philosophical interpretation of the concept. Speaking about discourse as "language in language", Stepanov states the existence of discourse "primarily and mainly in texts, but those that are followed by a special grammar, a special lexicon, special rules of word use and syntax, a special semantics-ultimately, a special world." (Stepanov 1995, pp. 43-44).

However, the most popular interpretation of discourse in Russian linguistics is by all means the laconic one proposed by Arutyunova, "a text immersed in life." (Arutyunova 1998) This definition is echoed by Karasik, who defines discourse as "a text in a communicative situation" (Karasik 2004, p. 198). Therefore, the concept of discourse involves its definition as a coherent text in combination with extralinguistic factors (pragmatic, sociocultural, psychological, etc.). This approach correlates with that of Van Dijk, who identifies two levels of the notion of discourse. The broad meaning of the term refers to discourse as a complex communicative event or action, and the narrow one as a text or conversation. A communicative event or action can be verbal, written, or have both verbal and non-verbal components (van Dijk 2000). Thus, the heterogenous and multifaceted nature of discourse gave rise to its numerous interpretations presented in philosophical and linguistic research. The review and systematization of these interpretations allow 
scholars (see, for example, T. Dobrosklonskaya (2014)) to identify several approaches to its definition: (1) the structural approach, which focuses on the context and extralinguistic factors; (2) the functional approach, which demonstrates the relationship with various spheres of human activity - political, media, scientific etc.; (3) the thematic approach, which defines the spheres of communication that can be distinguished on the basis of the proximity of individual characteristics, for example, authorship (author's discourse), or a theme (ecological discourse, gluttonic discourse, etc.). All these approaches focus on discourse as language in use, as opposed to language as a system. It also seems to be widely assumed that discourse is "determined by context, which generates text and determines its structure" (Ponton and Larina 2016, p. 8). According to Kecskes, context, as any factor that influences the meaning and interpretation of linguistic signs, can be categorized into external context, psychological context, and prior context (Kecskes 2014a), of which prior context is of special interest since it "develops through the regularity of recurrent and similar situations, which we tend to identify with given contexts" (Kecskes 2014b, p. 215). The most important context is culture, which includes religion as its major component.

Thus, in further sections, eastern religious discourse is treated from the linguistic perspective, which involves considering both linguistic and extralinguistic features of religious communication.

\section{Materials and Methods}

The objective of the study to reveal the transformations taking place in religious discourse under digitalization determines the use of such methods as descriptive-analytical, contextual, and discourse analysis. The choice of a unit of discourse analysis is motivated by the research objectives. In the proceeding sections, a communicative event is regarded as the main discourse unit since it possesses the following features: duration, participants and boundaries, setting, theme, some featured rules of interaction; it is isolated from the flow of events, and it is causal. A speech genre will also be regarded a discourse unit since it enters into various relations with a communicative event. Since discourse analysis embraces, in fact, a large group of various linguistic approaches, we rely on the major differentiation between descriptive and critical discourse analyses suggested for political discourse (Chilton 1994). In this paper, the descriptive approach focuses on linguistic means and rhetorical and manipulative techniques used in in eastern orthodox religious discourse. Some elements of critical discourse analysis are also used since the position of the official ROC is under study: "CDA (Critical Discourse Analysis) takes a particular interest in the relationship between language and power. The term ' $\mathrm{CDA}^{\prime}$ ' is used nowadays to refer more specifically to the critical linguistic approach of scholars who find the larger discursive unit of text to be the basic unit of communication." (Weiss and Wodak 2003, pp. 12-14). Both approaches seem to be relevant for studying religious discourse.

The empirical material of the present study includes excerpts from the video programs Live call-in show. The priest's answer, A day of the Patriarch broadcast on the Russian orthodox TV channel Spas; the texts of the interviews with His Holiness Patriarch Kirill of Moscow and All Russia and the late Patriarch Alexy II of Moscow and All Russia; a set of interviews under the general title The Orthodox perspective on a YouTube channel; materials from the official websites of the Russian Orthodox Church and the Moscow Patriarchate (http:/ / www.patriarchia.ru/; https: / / mospat.ru / (accessed on 4 January 2021)); live broadcasts of Divine Liturgies; materials of various Orthodox Christian forums and groups; and media texts and journalistic articles that form a so-called "reaction discourse". This term was first coined by Plotnikova to denote any discourse produced in response to a politician's discourse (Plotnikova 2005). In this paper, this term refers to any kind of discourse produced as a response to religious events, i.e., any manifestations of religious discourse. 


\section{Results and Discussion}

\subsection{Religious Discourse and Its Genres}

Discourse studies have drawn linguists' attention to various types of institutional discourses (Karasik 2004, pp. 208-39), and religious discourse, especially the discourse of the Russian Orthodoxy, has experienced a research boom. Among the works that focus on linguistic aspects of religious discourse are Karasik $(1999,2004)$, who proposed the general theory of religious discourse; Rastorgueva (2005); Zvezdin (2012), who analyzed the sermon as a genre of religious discourse in Russian Orthodoxy; Golberg (2002), who studied the moral concepts of the religious-preaching style in the modern Russian literary language; Kaznina (2004), who described the concept of faith in modern religious discourse; Mechkovskaya (1998), who examined the genres of religious discourse and described the communicative features of mythological and religious practices, exploring the relationship between religion and language and their mutual influence on each other; and many others. According to Karasik, the structure of religious discourse comprises goals, values, strategies, chronotope, texts, their varieties and genres, material (oral and/or written), and participants (agents, clients) (Karasik 2004, p. 266). Nevertheless, two research papers should be specifically mentioned as being of particular importance to the present analysis since they describe the genres and language of modern eastern orthodox discourse. Bobyreva suggests the following definition of religious discourse: "Institutional communication, the purpose of which is to introduce a person to faith or strengthen his/her faith in God, and which is characterized by the following constitutive features (1) its content is sacred texts and their religious interpretation, as well as religious rituals, (2) its participants are clergy and parishioners, (3) its typical chronotope is temple worship." (Bobyreva 2007, p. 5). The author also distinguishes three subtypes of religious discourse: (a) communication in the temple/church as the main religious institution; (b) communication in small religious groups-the process of communication takes place not in the temple/church, but outside it; (c) communication of a person directly with God without any mediators, for example through a prayer (Bobyreva 2007, pp. 9-11). As for the genres of religious discourse, the researcher admits the difficulty in distinguishing them and divides all the genres into primary and secondary ones. The speech genres of parables, psalms, and prayers belong to the primary ones. The secondary genres are the sermon and confession; they are a kind of modification of primary religious genres (Bobyreva 2007). This lack of genre variety is argued in Bugaeva (2010) who suggests a different criterion for categorizing religious discourse genres, namely, the spheres of usage. Thus, the author suggests distinguishing the following genres: genres of the Scripture, and liturgical, instructive, administrative, and etiquette genres with their further detailed sub-categorization (Bugaeva 2010, p. 37). She also comments on some genre transformations that occur in religious discourse. These transformations touch upon both formal and content-related aspects of a particular genre. For instance, such genre as application ("zayavleniye") has preserved the name of petition ("prosheniye") together with its formal characteristics, while the genre of "zhitiya" or hagiology has evolved into "zhizneopisaniya" or life descriptions (Bugaeva 2010). Thus, it seems quite obvious that human faith in God is represented through a set of basic religious concepts embodied in verbal and non-verbal means of their expression in religious discourse. If we take the language of monks who live in an isolated monastery environment, it contains the lexico-grammatical core of religious discourse. The discourse of the clergy outside monasteries is likely to be close to the literary norm while preserving the specific elements of the "orthodox church" language at the same time. However, the digitalization of society inevitably exerts influence on those who use these new technologies. Observing monks at some eastern orthodox monasteries, I saw many of them use mobile phones, tablets, and other technological advances of modern digital era, not to mention priests and students of ecclesiastical academies and seminaries. The specifics of digital communication find their reflection in the religious discourse. 


\subsection{Evolution of Some Genres of Religious Discourse}

Speech genres are a basic concept of discourse studies. Modern discourse theories of speech genres are based on a variety of approaches (see Arutyunova 1999; Bakhtin 1996; Borisova 2005; Goldin 1997; Dement'ev 2010; Dolinin 1999; Kibrik 2009; Sedov 1999; Sirotinina 1999; Shmeleva 1997; van Dijk 1989, et al.). It is also the variety of speech genres that Dement'ev called a major obstacle to their linguistic study (Dement'ev 2010, p. 77). A popular model of a speech genre includes the following components: a communicative goal, the author's statement, the addressee's statement, a communicative past factor, a communicative future factor, eventive content, and linguistic embodiment (Shmeleva 1997). According to Borisova, a speech genre is based on a communicative goal, which depends on the social context, the type of social interaction, and social norms (Borisova 2005). Many researchers focus on the social aspect of speech genres stating that it is impossible to research speech genres in isolation from their communicative reality (Goldin and Dubrovskaya 2002). In any case, a speech genre should be treated as a speech unit larger that a speech act; it is a part of a communicative event, although one particular speech genre could be part of several communicative events simultaneously.

Genres of religious discourse, as it was mentioned above, can be classified along different lines (Bobyreva 2007). Since religious discourse is, first and foremost, an institutional type of discourse, one of the possible suggested genre classifications is a classification according to the degree of its institutionality. If we draw a scale of institutionality from the minimal to the maximal degree, then genres such as anecdotes and jokes on religious subjects should be placed at its minimal end, while the Bible, psalms, and parables placed at its maximal end, and all other genres being placed in between. In her research, Bobyryeva provides a detailed list of religious genres that were identified almost 15 years ago, including TV addresses of church fathers (Bobyreva 2007, pp. 170-79). Now, let us look at some transformations that religious genres in the Russian Orthodox discourse have undergone due to technological innovations.

I would like to start with the genre of TV sermon that first appeared on Russian television in the mid-1990s. A sermon is traditionally defined as a monologue on a moral or religious subject, usually given by a religious leader during a church service in order to instruct the listener on some aspects of faith and godly life. From the rhetorical perspective, it is a type of speech manipulation, the purpose of which is to persuade people to lead godly life in accordance with Christian values. The theological and anti-rhetorical approaches to the sermon were described in a number of papers (see, for example, Krymskaya 2006; Prohvatilova 1999; Zvezdin 2012). I would stick to the "secular" definition of the sermon. From the perspective of discourse linguistics, a sermon is "a speech delivered by a clergyman before a congregation of believers on a specific occasion, on a specific subject, with the aim of a specific religiously motivated influence on the addressee. It contains such components as communicants, communicative intention and purpose, a communication channel, and the message itself (the verbal component of a sermon)." (Bobyreva 2007, p. 219). Any sermon is a communicative act of interaction between an individual addresser and a collective non-homogeneous addressee, the only conditio sine qua non for an effective sermon being shared faith. The air of sharing the same faith, the feeling of involvement, and the location itself (the temple) contribute to achieving the communicative goal.

A TV sermon suggests a much larger audience, on the one hand, and less atmospheric location, on the other. People tend to listen to digital sermons from their homes, cars, summer houses, etc., where the feeling of interconnectedness and togetherness is substantially weakened. Thus, digital means have to compensate for this lack of involvement, and therefore the eastern orthodox preachers make moderate use of images, slides, video clips, and sound effects that they never use during traditional sermons in a church building. Let us consider an Orthodox TV program, A Day of Patriarch, broadcast on the Russian religious TV channel Spas. The program presents fragments of Patriarch Kirill's daily life and activities, his pastoral trips, public speeches, and other events. However, the bulk 
of the program is devoted to Patriarch's sermons on the most topical religious and social issues. All Patriarch's sermons are actual sermons delivered offline and then edited for TV presentation. Every sermon is accompanied by a corresponding visual backdrop, quiet music, and footage of the congregation carefully listening to the voice of the patriarch. No special visual or audio effects, just serious serene faces in the solemn atmosphere of a temple. Russian Orthodox TV sermons tend to be as close to the traditional sermons as possible in order to preserve and recreate the atmosphere of piety and adoration at a live sermon.

A genre of religious discourse that appeared due to digital technologies and benefitted from them is the genre of reading aloud Biblical texts. Originated at religious schools/Sunday schools, this genre is flourishing in the Russian Orthodox religious channels. The most popular technique is attracting famous actors, producers, and journalists to read Biblical texts aloud to the accompaniment of pleasant quiet music and corresponding video sequence. One of the recent projects involving the most popular Russian actors and producers is presented at http://spastv.ru/shows/novyj-zavet-vsluh/ and http:/ / spastv.ru/blog/2019/01/07/evangelie-vsluh-chetyre-knigi-evangelija-ustamiizvestnyh-ljudej/ (accessed on 4 January 2021). The narrators do not add any comments or extra-textual information, the desired pragmatic effect being achieved through the use of paralinguistic (voice qualities), prosodic, and extralinguistic (video and audio) means.

Another religious genre that originated and spread due to digital technologies is the broadcast commented church service. This genre is derived from the "missionary service"a specific genre of religious discourse that was established through The Conception of missionary activity of the Russian Orthodox Church in 2007. The communicative goal of this genre is to educate baptized/non-baptized and/but not religiously educated members of the Russian Orthodox Church. Therefore, the "missionary service", of which the missionary Liturgy is the most common event, is a Divine Liturgy with commentaries, the purpose of which is to educate and bring to church people who consider themselves Orthodox Christians or want to become Orthodox Christians. This genre has gained significant popularity in the last decades-today, Google offers 652,000 websites to reply the user's request "missionary service", but very few, if any, of them reflect linguistic and discourse features of this genre. From the discourse perspective, a missionary service is a hybrid genre combining a primary genre of religious service (liturgy) and a genre of commentary aimed at clarifying the ongoing events. The analysis of TV commented Liturgies broadcast between 2014 and 2021 allowed for the distinguishing of four main types of comments:

(1) Comments explaining the religious terminology (e.g., "Liturgy is the main service of the Christian Church during which the sacrament of the Eucharist takes place and during which all worshippers have an opportunity to receive Holy Communion of Corpus Christi" (https:/ / www.youtube.com/watch?v=kQy0eMtWUWE (accessed on 8 January 2021)); "The Choir reply 'Amen', that is, 'so be it'. 'The sun of righteousness' and 'the east from above' refer to Jesus Christ, who enlightened people with his teaching." (https: / / www.youtube.com/watch?v=WDAMK-720eI (accessed on 8 January 2021));

(2) Comments explaining the acts and moves of the clergy during the church service (e.g., "We see the royal gates open and Patriarch with the serving clergy go to the center of the temple in order to begin the service of the All-Night Vigil and the Divine Liturgy here. The choir of the Cathedral of Christ the Savior performs the solemn hymn "God is with us". Music by Priest Vasily Zinoviev". (https://www.youtube.com/watch?v= WYbFsynxBWg (accessed on 8 January 2021)) "The service begins with an exclamation from the Patriarch." (https:/ / www.youtube.com/watch?v=WYbFsynxBWg (accessed on 8 January 2021)). These types of comments are the most frequent one among the other types;

(3) Comments explaining the historical background of events (e.g., "The chant is based on the prophecy of Isaiah. This prophet, who lived 700 years before the birth of Christ, announced the future birth of the Savior from a virgin, prophesied about many events of his earthly life, as well as about the sufferings that the son of God had to accept in the name 
of saving the human race" (https:/ / www.youtube.com/watch?v=LD6na2rbrUE (accessed on 8 January 2021));

(4) Comments explaining the purpose of a particular action ("In the Orthodox tradition, there is a certain symbolism of color; it concerns, first of all, certain vestments in which the clergy are dressed. And today it is the color of gold-the color of "the Sun of the Truth." "All elements of the divine service, including the decoration of the temple, the exclamations of the clergy, the singing of the choir are subordinated to a single goal-to tune a person to a prayer mood, to help his/her mind and heart to unite with the Lord" (https:/ / www.youtube.com/watch?v=WDAMK-720eI (accessed on 8 January 2021)).

There is one more type of commentary, which is not a commentary but a "translation" of church hymns from the Church Slavonic into modern Russian language, the purpose of which is to draw listeners' attention to the most meaningful lines of a hymn and to help the audience correctly interpret the theological meaning of a text. All these types of comments are made either in pauses between the moves of the clergy or simultaneously with the church service. The latter can be viewed as a specific feature of TV commented church service, since the original recommendations to missionary services include providing a commentary either before or after the service or publishing special booklets that are given to the visitors before the church service (Danilov 2014). Thus, by using live broadcasts of commented church services and publishing them on YouTube and other Internet channels, the ROC fulfills its educational and awareness-raising mission, stimulating laypeople's interest to religious traditions and Christian values in general.

Another genre that appeared in Eastern Orthodox religious discourse recently is the orthodox call-in show. For example, the Spas TV channel offers a call-in program A Priest's Answer, which provides an opportunity to talk with a priest using digital technologies. The questions can be asked through the telephone, social networks, the channel's website, or web application (http:/ / spastv.ru/shows/otvet-svjashhennika (accessed on 4 January 2021)). The range of subjects discussed is rather wide, but the majority address purely religious issues, such as the interpretation of the Bible and other religious texts; eastern orthodox traditions; and rituals, proper Christian behavior, diet, etc. Nevertheless, there are quite a large number of questions from the audience that touch upon social and moral issues, for example, the attitude towards competitors, horoscopes, and addictions (smoking, drugs, alcohol). It should be noted that priests who answer questions read them from tablets, demonstrating no conflict between electronic devices, traditional orthodox priests' clothing, Biblical parables, and usage of the religiolect. ${ }^{2}$

It should also be noted the language of "digitalized" religious discourse is also undergoing significant change-the vocabulary used for TV sermons, commented church services, interviews, etc. is getting much closer to the publicist discourse than to the eastern orthodox religiolect, although not completely lacking it (see Bugaeva 2010). The purpose seems obvious - on the one hand, the clergy have to preserve the atmosphere of unity and belonging to some elevated community of spiritual people, on the other, the laypeople should never feel alienated by specific religious vocabulary and structures. Moreover, TV sermons often revolve around touchy social subjects, not only purely religious or moral ones. Thus, digital religious discourse serves to bring up topical social issues in religious context.

Apart from the religious discourse genres proper, the modification of which has been considered above, a number of other genres were identified that cannot be referred directly to the religious discourse but "surround" or accompany it. They are eastern orthodox forums, blogs, podcasts, talk shows, televised debates, interviews, and other "secular" genres of media discourse borrowed and adapted for religion-associated purposes. They form what I would call "para-religious discourse", i.e., discourse that has two main unifying features-at least one of the participants should be a clergyman (or a "professional Chris-

2 Religiolect is "a relatively stable socially marked subsystem of the national language, serving the speech needs of a limited social group of believers, reflecting the theocentric picture of the world and characterized by phonetic, lexical, word-formation, and grammatical features". (Bugaeva 2010, p. 41). 
tian") acting in his / her professional capacity, and discussions should apply to precedent texts, namely, the texts of the sacred scriptures and other original religious sources. Even a pilot survey of these resources revealed a variety of discourse strategies and tactics used by communicators, among which are the cooperative strategy, confrontational strategy, tactics of agreement, appraisal, appeal to authority, and many others. The language of para-religious discourse includes a variety of religious vocabulary and structures intertwined into everyday speech. Para-religious discourse in the digital environment is an immense layer that requires thorough analysis in order to reveal its discourse specifics in comparison with the "secular" internet communication.

\section{Conclusions}

The transformations that have taken and are taking place in eastern orthodox religious discourse in the digital epoch stem from two main factors: the necessity to adapt to modern digital environment and benefit from organizing the internet space in order to influence large numbers of "digitally educated" non-religious (young) people, and, at the same time, a distrust of these new digital technologies. Russia needs to unite its people, and the Russian Orthodox Church strives to fulfill this function while resisting any dramatic digital transformation. Orthodox religious discourse responds to digitalization both through creating orthodox websites, blogs, forums, and TV channels, and through modifying its linguistic component. Through the Internet and other digital resources, the Russian Orthodox Church actively disseminate Orthodox ideas and values among non-religious internet users, especially those who distance themselves from socio-political activity. Nowadays, religious discourse is being transformed into a specific discursive product with a completely different composition of participants, since potentially every internet user and/or TV viewer can become a recipient of religious or para-religious texts in the broadest sense of this word. The chronotope of religious discourse is no longer restricted to the temple worship - it is virtually boundless, limited only by the desire of the potential recipients to participate in it. We are witnessing both the transformation of old genres of religious discourse, such as the sermon or church service, and the creation of new ones, such as the commented liturgy and call-in show. Due to digital technologies, while retaining its goal, religious discourse penetrates into everyday life of people regardless of their social status and religious affiliation. Thus the borderline between the church and society in modern Russia is being eliminated. Nevertheless, advanced computer technologies and highly technological visual and audio effects are avoided in creating digital religious products, which could be explained by the generally apprehensive attitude of the ROC to the new frontiers of the digital world.

Funding: This paper has been supported by the RUDN University (Peoples' Friendship University of Russia) Strategic Academic Leadership Program.

Conflicts of Interest: The author declares no conflict of interest.

\section{References}

Arutyunova, Nadezhda D. 1998. Discourse. In Linguistics. Big Linguistic Dictionary. Moscow: Bolshaya Rossiyskaya Encyclopedia, pp. 136-37. (In Russian)

Arutyunova, Nadezhda D. 1999. Human Language and World. Moscow: Languages of Russian Culture. (In Russian)

Bakhtin, Mikhail M. 1996. The Problem of Speech Genres. In Collected Works. Moscow: Russkiye Slovari, vol. 5, pp. 159-206. (In Russian)

Bobyreva, Yekaterina V. 2007. Religious Discourse: Values, Genres, Strategies (Based on the Material of Eastern Orthodoxy). Volgograd: Peremena. (In Russian)

Borisova, Irina N. 2005. Russian Conversational Dialogue: Structure and Dynamics. Moscow: ComBook. (In Russian)

Bugaeva, Irina V. 2010. The Language of Orthodox Believers in the Late XX-Early XXI Century. Thesis for the Degree of Doctor of Philology, Pushkin State Russian Language Institute, Moscow, Russia. (In Russian)

Burtsev, Vladimir A. 2012. Discourse of Russian Orthodox Sermon: Methods of Making Utterances. Ph.D. thesis, Yelets University, Russian Federation, Yelets, Russia. (In Russian) 
Chilton, Paul A. 1994. Politics and Language. In The Encyclopedia of Language and Linguistics. Edited by Ronald E. Asher. Oxford and New York: Pergamon Press, pp. 3214-21.

Danilov, Antony. 2014. Missionary Worship. Education and Orthodoxy. Electronic Journal. Available online: http://www.orthedu.ru/ journal/9386-missionerskoe-bogosluzhenie.html (accessed on 1 December 2020). (In Russian)

Dement'ev, Vadim V. 2010. Theory of Speech Genres. Moscow: Znak. (In Russian)

Dobrosklonskaya, Tatyana G. 2014. Mass Media Discourse in the Modern System of Discursive Practices. In Discourse as Social Activity: Priorities and Perspectives. Moscow: MSLU, pp. 106-8. (In Russian)

Dolinin, Konstantin A. 1999. Speech Genres as a Means of Organizing Social Interaction. In Genres of Speech 2. Saratov: "College", pp. 7-13. (In Russian)

Foucault, Michel. 1972. The Archaeology of Knowledge and the Discourse on Language. New York: Pantheon Books.

Golberg, Inna M. 2002. The Religious and Preaching Style of the Modern Russian Literary Language: Moral Concepts. Thesis for the Degree of Candidate of Philology, Moscow State Pedagogical University, Moscow, Russia. (In Russian)

Goldin, Valentin E. 1997. The Names of Speech Events, Actions and Genres of Russian Speech. In Genres of Speech 1. Saratov: "College", pp. 23-34. (In Russian)

Goldin, Valentin E., and Olga N. Dubrovskaya. 2002. Genre Organization of Speech in the Aspect of Social Interactions. In Genres of Speech 3. Saratov: "College", pp. 5-17. (In Russian)

Karasik, Vladimir I. 1999. Religious Discourse. In Language Personality: Issues of Cultural Linguistics and Functional Semantics. Volgograd: Peremena, pp. 5-19. (In Russian)

Karasik, Vladimir I. 2004. Language Circle: Personality, Concepts, Discourse. Moscow: Gnozis. (In Russian)

Kaznina, Elena B. 2004. The Concept of Faith in Dialogical Christian Discourse. Thesis for the Degree of Candidate of Philology, RUDN University, Moscow, Russia. (In Russian)

Kecskes, Istvan. 2014a. Intercultural Pragmatics. Oxford: Oxford University Press.

Kecskes, Istvan. 2014b. Word, Context and Communication Meaning. Russian Journal of Linguistics 4: 40-153.

Kibrik, Andrey A. 2009. Mode, Genre and Other Parameters of the Classification of Discourses. Issues of linguistics 2: 3-21. (In Russian)

Krymskaya, Elena V. 2006. Sermon as a Genre of Oratory. In Language. Culture. Communication: International Scientific Conference. Collected Works. Part 3. Volgograd: Volgograd Scientific Publishing House, pp. 109-16. (In Russian)

Mechkovskaya, Nina B. 1998. Language and Religion. Moscow: FAIR. (In Russian)

Plotnikova, Svetlana N. 2005. A Politician as a Constructor of Reaction Discourse. In Political Discourse in Russia 8: Saints without Hagiography: Materials of Standing Seminar. Edited by Vladimir N. Bazylev and Varvara G. Krasilnikova. Moscow: MAKS Press, pp. 22-26. (In Russian)

Ponton, Douglas, and Tatyana Larina. 2016. Discourse Analysis in the 21st Century: Theory and Practice (I). Russian Journal of Linguistics 20: 7-25. [CrossRef]

Prohvatilova, Olga A. 1999. Orthodox Sermon and Prayer as a Phenomenon of Modern Sounding Speech. Volgograd: Volgograd State University. (In Russian)

Rastorgueva, Marina B. 2005. Speech Genre of Church-Religious Sermon. Thesis for the Degree of Candidate of Philology, Voronezh State University, Voronezh, Russia. (In Russian)

Sedov, Konstantin F. 1999. On the Genre Nature of the Discourse Phenomenon of a Linguistic Personality. In Genres of Speech 2. Saratov: "College", pp. 13-26. (In Russian)

Shmeleva, Tatyana V. 1997. A Speech Genre Model. In Genres of Speech 1. Saratov: “College”, pp. 88-98. (In Russian)

Sirotinina, Olga B. 1999. Some Reflections on the Term "Speech Genre" and "Rhetorical Genre". In Genres of Speech 2. Saratov: "College", pp. 26-30. (In Russian)

Stepanov, Yuri S. 1995. Alternative World, Discourse, Fact and the Principle of Causality. In Language and Science of the Late XX Century. Moscow: RSUH, pp. 34-73. (In Russian)

van Dijk, Teun A. 1989. Language. Cognition. Communication. Moscow: Progress. (In Russian)

van Dijk, Teun A. 2000. Ideology and Discourse. A Multidisciplinary Introduction. London: SAGE Publication Ltd.

Weiss, Gilbert, and Ruth Wodak. 2003. Introduction: Theory, Interdisciplinarity and Critical Discourse Analysis. In Critical Discourse Analysis: Theory and Interdisciplinarity. Edited by Gilbert Weiss and Ruth Wodak. London: Palgrave Macmillan Ltd., pp. 1-32.

Zvezdin, Dmitry A. 2012. Orthodox Sermon as a Genre of the Church-Religious Style of the Modern Russian Literary Language: On the Example of the Texts of the Second Half of the 20th Century. Thesis for the Degree of Candidate of Philology, Chelyabinsk Pedagogical University, Chelyabinsk, Russia. (In Russian) 